\title{
Sistem Informasi Pariwisata Berbasis Website Pada Taman Nasional Gunung Ciremai Jawa Barat
}

\author{
Sagita Utarki ${ }^{1}$, Eva Argarini Pratama ${ }^{2}$, Corie Mei Hellyana ${ }^{3}$ \\ Universitas Bina Sarana Informatika ${ }^{123}$ \\ 1ssagitautarki@gmail.com, ${ }^{2}$ eva.eap@bsi.ac.id, ${ }^{3}$ corie.cma@bsi.ac.id
}

\begin{abstract}
Tourism sector in the country is one of the mainstay of foreign exchange earners for the country, especially in the non oil and gas sector, all efforts to attract tourists both archipelago and overseas continue to be done. One of the government's efforts to increase the flow of domestic and foreign tourists is to make improvements and arrangement of tourist attractions. In addition, by promoting. Therefore required a system that can facilitate the management of tourism in data processing, and facilitate members or tourists in obtaining information. Technological developments are increasing, then from the problems proposed a change in the old system into a new system with computer-based website technology. The method used in the development of this software uses Model Waterfall. Data collection methods that the authors use to collect the data needed in the writing of this research are: observation, interview method, and literature method. Through a computer connected to the internet network users can search and get various information, anywhere and anytime by accessing the website. With this system, is expected to overcome the various needs of users to obtain information and help the government to increase local revenue.
\end{abstract}

\section{Keywords: Information Systems, Tourism, Website, Waterfall}

\begin{abstract}
Abstrak: Sektor pariwisata di tanah air merupakan salah satu andalan penghasil devisa bagi negara khususnya pada sektor non migas, segala upaya untuk menarik wisatawan baik nusantara maupun mancanegara terus dilakukan. Salah satu upaya pemerintah untuk meningkatkan arus wisatawan nusantara dan mancanegara adalah dengan melakukan pembenahan dan penataan objek wisata. Selain itu juga dengan melakukan promosi. Maka dari itu dibutuhkan sistem yang dapat mempermudah pengelola wisata dalam mengolah data, serta mempermudah anggota atau wisatawan dalam memperoleh informasi. Perkembangan teknologi yang semakin meningkat, maka dari permasalahan tersebut diusulkan adanya perubahan sistem lama kedalam sistem yang baru dengan teknologi komputer berbasis website. Metode yang digunakan pada pengembangan perangkat lunak ini menggunakan Model Waterfall. Metode pengumpulan data yang digunakan untuk mengumpulkan data-data yang diperlukan dalam penelitian ini yaitu: observasi, metode wawancara, dan metode pustaka. Melalui komputer yang terkoneksi dengan jaringan internet user dapat mencari dan mendapatkan berbagai informasi, dimana saja dan kapan saja dengan mengakses website. Dengan adanya sistem ini, diharapkan mampu mengatasi berbagai kebutuhan user untuk memperoleh informasi serta membantu pemerintah meningkatkan pendapatan daerah.
\end{abstract}

Kata kunci: Sistem Informasi, Pariwisata, Website, Waterfall

(i)(2) This is an open access article distributed under the Creative Commons Attribution License, which permits unrestricted use, distribution, and reproduction in any medium, provided the original work is properly cited. (2019 by author and IJSE-Indonesian Journal on Software Engineering.

\section{A. PENDAhUluan}

Sektor pariwisata di tanah air merupakan salah satu andalan penghasil devisa bagi negara khususnya pada sektor non migas, segala upaya untuk menarik wisatawan baik nusantara maupun mancanegara terus dilakukan. Adapun upaya-upaya yang dilakukan adalah dengan mempromosikan kepariwisataan di Indonesia, dengan pengembangan wisata dan sapta pesona maupun program-program lainnya. Pengembangan- 
pengembangan wisata pun dilakukan oleh setiap daerah di Indonesia termasuk juga Provinsi Jawa Barat yang mempunyai potensi pariwisata yang cukup beragam.

Provinsi Jawa Barat sebagai salah satu provinsi di Indonesia memiliki banyak objek wisata yang dapat dijadikan andalan pendapatan, hal ini adalah suatu peluang bagi Jawa Barat bagaimana mengelola potensi-potensi yang ada dimanfaatkan secara optimal dalam rangka pencapaian nasional. Salah satu upaya pemerintah untuk meningkatkan arus wisatawan nusantara dan mancanegara adalah dengan melakukan pembenahan dan penataan objek wisata. Selain itu juga dengan melakukan promosi. Menurut Kotler dan Ketler dalam [Novena, 2013] mengatakan bahwa, "secara umum promosi adalah suatu komunikasi dari penjual dan pembeli yang berasal dari informasi yang tepat yang bertujuan untuk merubah sikap dan tingkah laku pembeli, yang tadinya tidak mengenal sehingga menjadi pembeli dan tetap mengingat produk tersebut". Pengembangan dan peningkatan pariwisata tentu tidak akan berjalan berdiri sendiri tetapi memerlukan dukungan dari berbagai kalangan, baik itu pemerintah daerah sendiri, instansi yang terkait, pihak swasta, maupun masyarakat.

Salah satu upaya pengembangan dan peningkatan pariwisata di Provinsi Jawa Barat adalah Kabupaten Kuningan. Kabupaten Kuningan memiliki pemandangan panorama alam yang indah, hawa sejuk (natural and fresh tourism objects) dengan temperatur rata-rata sekitar $18-32^{\circ} \mathrm{C}$ dan memiliki objek dan daya tarik yang cukup potensial serta didukung oleh budaya kesenian daerah yang beraneka ragam (various unique traditional art), sehingga Kabupaten Kuningan cocok dijadikan tempat peristirahatan dan tempat tujuan wisata. Khususnya di daerah Taman Nasional Gunung Ciremai, disana merupakan salah satu tempat yang menyimpan seribu keindahan dan keanekaragaman alam, seperti air terjun, bukit-bukit, pemandangan alam yang indah serta tempat foto yang menarik dan unik. Atas dasar identifikasi masalah yang telah dipaparkan di atas, maka rumusan masalah pada penelitian ini adalah bagaimana membuat sistem informasi pariwisata pada suatu daerah meningkatkan pendapatan daerah.

B. TINJAUAN PUSTAKA

1. Sistem

Menurut Jogianto dalam Hamim Tohiri dalam [Saryoko, 2017] mengatakan bahwa, "sistem adalah kumpulan elemen-elemen yang berinteraksi untuk mencapai tujuan tertentu". Sedangkan menurut Tata Sutabri dalam [Supriyatna, 2015] mengatakan bahwa, "sistem adalah suatu kumpulan atau himpunan dari unsur-unsur, komponen atau variable yang terorganisir, saling terintegrasi, saling berinteraksi, saling tergantung satu sama lain dan terpadu".

\section{Informasi}

Menurut Sutabri dalam [Handayani et al., 2018] menjelaskan bahwa, "Informasi adalah data yang diklasifikasikan atau diolah atau diinterpretasikan untuk digunakan dalam proses pengambilan keputusan".

Menurut Mc Leod dalam [Imaniawan and Elsa, 2017] mengatakan suatu informasi yang berkualitas harus memiliki ciri-ciri:

a. Akurat, artinya informasi harus mencerminkan keadaan sebenarnya.

b. Tepat waktu, artinya informasi itu harus tersedia atau ada pada saat informasi tersebut diperlukan, tidak besok atau tidak beberapa jam lagi.

c. Relevan, artinya informasi yang diberikan harus sesuai dengan yang dibutuhkan.

d. Lengkap, artinya informasi harus diberikan secara lengkap.

\section{Sistem Informasi}

Menurut Stair dan Reynolds dalam [Wiguna, 2017] mengatakan bahwa, "Sistem informasi (SI) adalah seperangkat komponen yang saling terkait dalam mengumpulkan, memproses, menyimpan, serta menyebarkan data dan informasi".

Menurut Jogiyanto dalam [Supriyatna, 2015], "sistem informasi adalah suatu sistem di dalam suatu organisasi yang mempertemukan kebutuhan pengolahan transaksi harian, mendukung operasi, bersifat manajerial dan kegiatan strategi dari suatu organisasi dan menyediakan pihak luar tertentu dengan laporan-laporan yang diperlukan". 
Sistem informasi secara teknis dapat didefinisikan sebagai sekumpulan komponen yang saling berhubungan, mengumpulkan atau mendapatkan, memproses, menyimpan dan mendistribusikan informasi untuk menunjang pengambilan keputusan dan pengawasan dalam suatu organisasi atau perusahaan. Selain itu sistem informasi juga dapat digunakan untuk membantu dalam menganalisis permasalahan, menggambarkan hal-hal yang rumit dan menciptakan produk baru [Supriyatna, 2015].

\section{Internet}

Menurut Mansur dalam [Rizaniar and Sardiarinto, 2015] mengatakan bahwa, "International Networking (internet) adalah sebuah jaringan yang menghubungkan komputer-komputer di seluruh dunia. Jaringan komputer secara dapat diartikan sebagai hubungan fisik komputer dengan komputer lainnya melalui sebuah media agar dapat bertukar data".

a. Website

Menurut Puspitosari dalam [Rizaniar and Sardiarinto, 2015] mengemukakan bahwa, "Website adalah seluruh informasi yang disediakan melalui jalur internet sehingga bisa diakses ddangkani seluruh dunia, selama terkoneksi dengan jaringan internet". Website juga merupakan komponen yang dinamis terdiri dari teks, gambar, animasi, video sehingga membuat tampilan menarik untuk dikunjungi. Secara garis besar, website dibagi menjadi tiga jenis:

1) Website Statis

Website statis adalah web yang tampilan halamannya tetap, jika akan melakukan perubahan pada halaman yang akan diubah maka halaman tersebut di ubah secara manual dengan cara mengedit langsung dari kode programnya.

2) Website Dinamis

Website dinamis adalah webseite yang dapat diubah tampilannya melalui webnya langsung tanpa harus mengubah dengan mengedit kode programnya.

3) Website Interaktif

Website interaktif adalah web yang digunakan untuk interaksi sekumpulan komunitas atau forum.

b. Web Browser

Menurut Unggul Utan Surfandi dalam Private Tutorial Enterprise dalam [Rizaniar and Sardiarinto, 2015] "Web Browser merupakan sebuah perangkat lunak yang memungkinkan pengguna untuk menampilkan dan berinteraksi dengan teks, gambar, dan informasi yang ada pada halaman web pada sebuah World Wide Web (WWW) atau Local Area Network".

c. Web Server

Web Server merupakan sebuah perangkat lunak dalam server yang berfungsi menerima permintaan (request) berupa halaman web melalui HTTP atau HTTPS dari klien yang dikenal dengan browser web dan mengirimkan kembali (response) hasilnya dalam bentuk halaman-halaman web yang umumnya berbentuk dokumen HTML (Solichin, 2016).

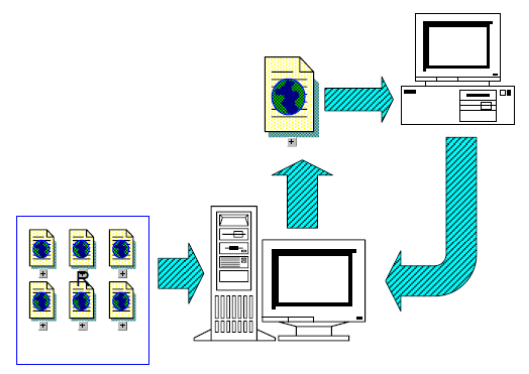

Sumber: [Solichin, 2016]

Gambar 1. Standar Web Architecture 


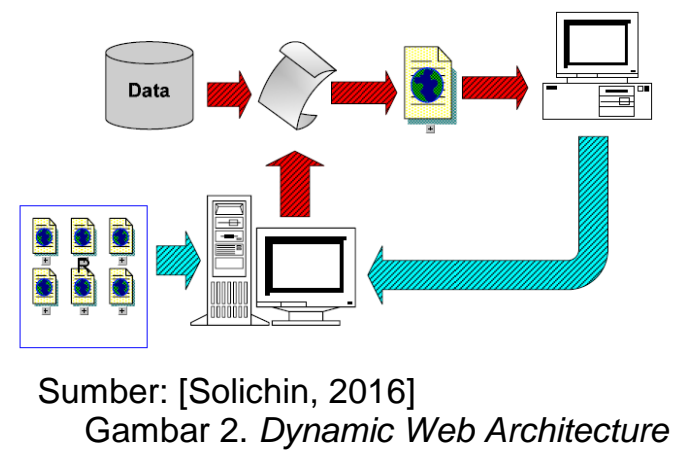

d. Hosting

Menurut Puspitosari dalam [Rizaniar and Sardiarinto, 2015] "Web hosting adalah suatu layanan jasa sebagai tempat atau wadah diinternet untuk perorangan atau badan organisasi menampilkan layanan jasa atau produknya di situs internet. Web hosting juga dapat menyimpan data berukuran megabytes sampai dengan terabytes sehingga data tersebut dapat diakses oleh semua pengguna. Web hosting juga merupakan sarana alternatif untuk penyebaran informasi dan promosi, layanan publik sampai dengan tempat sekedar untuk melakukan diskusi".

e. Domain

Menurut Rahmat dalam [Prasetyo, 2015], "Domain adalah alamat unik di dunia internet yang digunakan untuk mengidentifikasi sebuah website, atau dengan kata lain domain adalah alamat yang digunakan untuk mencari dan menemukan sebuah website pada dunia internet".

\section{Pariwisata}

Berbagai macam kegiatan wisata (kegiatan perjalanan yang dilakukan oleh seseorang atau sekelompok orang) dan didukung berbagai fasilitas serta pelayanan yang disediakan oleh masyarakat, pengusaha, Pemerintah, dan Pemerintah Daerah (Zebua, 2016).

\section{METODE PENELITIAN}

Rekayasa perangkat lunak (Software Enginering) merupakan pembangunan dengan menggunakan prinsip atau konsep rekayasa dengan tujuan menghasilkan perangkat lunak yang bernilai ekonomis yang dipercaya dan bekerja secara efisien menggunakan mesin. Secara umum model proses yang sering digunakan dalam komunitas perangkat lunak salah satunya dengan menggunakan model air terjun (waterfall mode).

Menurut (Rosa \& Shalahuddin, 2013), "Model SDLC air terjun (waterfall) sering juga disebut model sekuensial linier (sequential linier) atau alur hidup (classic life cycle). Model air terjun menyediakan pendekatan alur hidup perangkat lunak secara sekuensial atau terurut dimulai dari analisis, desain, pengkodean, pengujian, dan tahap pendukung (support)".

Berikut adalah gambar model air terjun:

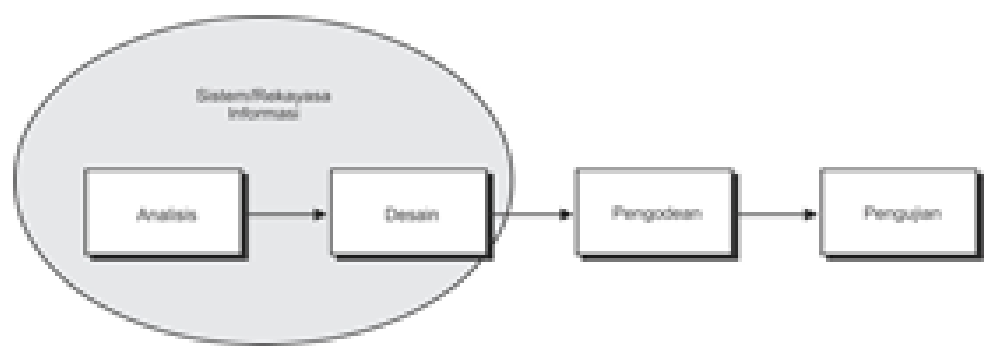

Sumber: (Rosa \& Shalahuddin, 2013)

Gambar 3. Ilustrasi Model Waterfall 
1. Analisa kebutuhan perangkat lunak

Proses pengumpulan kebutuhan dilakukan secara intensif untuk mespesifikasi kebutuhan perangkat lunak agar dapat dipahami perangkat lunak seperti apa yang dibutuhkan oleh user. Spesifikasi kebutuhan perangkat lunak pada tahap ini perlu didokumentasikan.

2. Desain

Proses multi langkah yang fokus pada desain pembuatan program perangkat lunak teramasuk struktur data, arsitektur perangkat lunak, representasi antarmuka, dan prosedur pengkodean. Tahap ini mentransilasi kebutuhan perangkat lunak dari tahap analisi kebutuhan ke representasi desain agar dapat diimplementasikan menjadi program pada tahap selanjutnya. Desain perangkat lunak yang dihasilkan pada tahap ini juga perlu didokumentasikan.

3. Pembuatan kode program

Desain harus ditranslasikan ke dalam program perangkat lunak. Hasil tahap ini adalah program komputer sesuai dengan desain yang telah dibuat pada tahap desain.

4. Pengujian

Pengujian fokus pada perangkat lunak secara segi lojik dan fungsional dan memastikan bahwa semua bagian sudah diuji. Hal ini dilakukan untuk meminimalisir kesalahan (error) dan memastikan keluaran yang dihasilkan sesuai dengan yang diinginkan.

5. Pendukung (support) atau Pemeliharaan (maintenance)

Tidak menutup kemungkinan sebauh perangkat lunak mengalami perubahan ketika sudah dikirimkan ke user. Perubahan bisa terjadi karena adanya kesalahan yang muncul dan tidak terdeteksi saat pengujian atau perangkat lunak harus beradaptasi dengan lingkungan yang baru. Tahap pendukung atau pemeliharaan dapat mengulangi proses pengembangan mulai dari analisis spesifikasi untuk perubahan perangkat lunak yang sudah ada, tapi tidak menutup kemungkinan membuat perangkat lunak baru.

\section{HASIL DAN PEMBAHASAN}

\section{Analisa Kebutuhan}

Analisa kebutuhan merupakan sebuah proses untuk mendapatkan informasi apa saja yang bisa dilakukan oleh user (pengunjung), member dan admin serta kebutuhan-kebutuhan yang diperlukan dalam pembuatan website ini.

a. Analisa Kebutuhan Pengguna

Dalam website Pariwisata pada Taman Nasional Gunung Ciremai ini terdapat 2 macam pengguna yaitu:

1) Admin

Admin merupakan pengguna yang dapat melakukan pengolahan data. Baik itu berhubungan dengan website seperti menambah, mengubah dan menghapus konten yang ada di website maupun melakukan kegiatan yang berkaitan dengan kegiatan pariwisata. Beberapa yang dibutuhkan oleh admin antara lain:

a) Admin membutuhkan akses untuk mengelola halaman website.

b) Admin membutuhkan sistem yang dapat mengelola data mengenai objek wisata, paket wisata, informasi tambahan, testimoni, maps, kontak, daftar member, proses pemesanan dan pembayaran paket wisata.

c) Admin membutuhkan informasi mengenai pemesanan dan pembayaran paket wisata.

d) Admin membutuhkan sistem yang dapat mengelola pendaftaran member.

e) Admin membutuhkan sistem yang dapat mencetak semua laporan dari setiap data seperti data pemesanan, pembayaran, daftar objek wisata, daftar member, dan laporan mengenai pemasukan dari pemesanan paket wisata setiap anggota.

2) Pengunjung

Pengunjung merupakan pengguna yang dapat mengakses halaman utama website ini. Berikut beberapa kebutuhan pengunjung diantaranya:

a) Pengunjung membutuhkan informasi yang ada di website ini.

b) Pengunjung membutuhkan informasi mengenai daftar objek wisata dan paket wisata yang ada di pariwisata Taman Nasional Gunung Ciremai Kuningan Jawa Barat.

c) Pengunjung membutuhkan tambahan rekomendasi tempat makan, pusat oleh-oleh, dan seni budaya yang ada di Kuningan melaui sarana informasi tambahan. 
d) Pengunjung apabila sudah menjadi member wisatawan membutuhkan informasi mengenai status pemesanan paket wisata dan informasi mengenai pembayaran yang harus dibayarkan.

3) Member

Member merupakan pengguna yang dapat mengakses halaman utama dan melakukan transaksi dalam website ini. Berikut beberapa kebutuhan member diantaranya:

a) Member membutuhkan informasi yang ada di website ini.

b) Member membutuhkan informasi mengenai daftar objek wisata dan paket wisata yang ada di pariwisata Taman Nasional Gunung Ciremai Kuningan Jawa Barat.

c) Member membutuhkan tambahan rekomendasi tempat makan, pusat oleh-oleh, dan seni budaya yang ada di Kuningan melaui sarana informasi tambahan.

d) Member membutuhkan akses untuk menambahkan testimoni pengunjung.

e) Member membutuhkan informasi mengenai status pemesanan paket wisata dan informasi mengenai pembayaran yang harus dibayarkan.

f) Member membutuhkan informasi mengenai konfirmasi pembayaran.

g) Member membutuhkan informasi mengenai data pribadi.

b. Analisa Kebutuhan Sistem

Beberapa kebutuhan sistem yang ada di website parwisata pada Taman Nasional Gunung Ciremai, diantaranya:

1) Pengolahan data

Dalam website pariwisata pada Taman Nasional Gunung Ciremai, terdapat beberapa data yang akan dikelola, diantaranya:

a) Data profil berupa sejarah dan struktur organisasi Dinas Pemuda, Olahraga dan Pariwisata Kuningan Jawa Barat.

b) Data member yang berisi informasi mengenai anggota yang telah terdaftar.

c) Data website yang berisi informasi mengenai daftar objek wisata dan paket wisata.

d) Data website yang berisi informasi tambahan mengenai tempat makan, pusat oleholeh, dan seni budaya yang ada di Kuningan.

e) Data transaksi mengenai informasi pemesanan dan pembayaran paket wisata.

f) Pembuatan laporan dari setiap data seperti transaksi pemesanan paket wisata, pembayaran paket wisata, total biaya yang diperoleh dari jumlah pemesanan paket wisata dalam periode tertentu.

2) Hak akses

Hak akses yang terdapat pada website ini dibagi menjadi dua bagian, yaitu:

a) Admin

(1) Halaman kelola website

(2) Halaman kelola data member

(3) Halaman kelola data admin

(4) Halaman kelola ganti password

(5) Halaman kelola pariwisata

(6) Halaman kelola fasilitas

(7) Halaman kelola paket

(8) Halaman kelola artikel

(9) Halaman kelola pemandu

(10)Halaman kelola testimoni

(11) Halaman kelola slide

(12) Halaman kelola laporan

(13) Halaman kelola informasi tambahan

(14)Halaman kelola transaksi pemesanan dan pembayaran paket wisata

b) Pengunjung
(1) Halaman beranda
(2) Halaman profil
(3) Halaman maps
(4) Halaman sejarah
(5) Halaman wisata
(6) Halaman kontak 
(7) Halaman registrasi

(8) Jika pengunjung sudah terdaftar menjadi member wisatawan, maka member dapat mengakses status pemesanan paket wisata.

c) Member
(1) Halaman beranda
(2) Halaman profil
(3) Halaman maps
(4) Halaman sejarah
(5) Halaman wisata
(6) Halaman kontak
(7) Halaman status pemesanan paket dan jumlah pembayarannya
(8) Halaman konfirmasi pembayaran
(9) Halaman login member

3) Keamanan

Website pariwisata pada Taman Nasional Gunung Ciremai ini membutuhkan sistem keamanan agar sistem berkerja. Selain itu, sistem keamanan juga mencegah serangan dari pihak yang akan menggangu berjalannya sistem. Beberapa sistem keamanan yang dibutuhkan antara lain:

a) Password yang digunakan untuk login dienkripsi agar tidak terbaca oleh pihak luar.

b) Terdapat sistem untuk ganti password pada setiap admin dan member.

c) Penggunaan captcha pada login admin, login member dan registrasi member.

d) Penggunaan validasi setiap form sebagai keamanan data.

\section{Rancangan Antarmuka}

Untuk memudahkan dalam perancangan website ini, maka rancangan dibuat harus digambar terlebih dahulu. Hal ini dimaksudkan agar memperjelas dan memudahkan dalam perancangan tampilan website Pariwisata pada Taman Nasional Gunung Ciremai. Rancangan tampilan website Pariwisata pada Taman Nasional Gunung Ciremai yaitu:

a. Rancangan Antar Muka Halaman Pengunjung

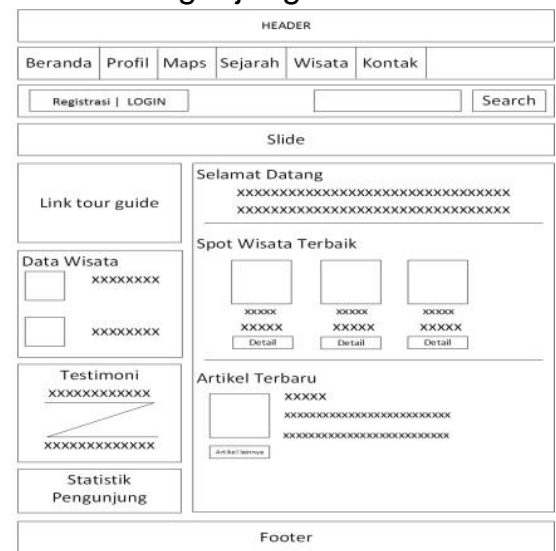

Gambar 4. Halaman Antar Muka Pengunjung

Rancangan halaman pengunjung adalah tampilan awal ketika pengunjung mengakses alamat website Pariwisata Taman Nasional Gunung Ciremai. Halaman ini terdiri dari beberapa bagian yaitu:

1) Header

Header, menampilkan logo pariwisata Taman Nasional Gunung Ciremai Kuningan Jawa Barat.

2) Menu, terdiri dari:

a) Beranda

Beranda merupakan halaman awal yang dimuat saat website diakses oleh pengunjung. Informasi yang terdapat dalam beranda adalah berita terbaru tentang pariwisata di daerah Taman Nasional Gunung Ciremai, berbagai macam pilihan wisata, dan agenda kegiatan yang dilaksanakan oleh Dinas Pemuda, Olahraga dan Pariwisata Kuningan dalam 1 bulan.

b) Profil 
Halaman profil menampilkan informasi tentang sejarah Dinas Pemuda, Olahraga, dan Pariwisata, visi misi, dan struktur organisasi Dinas Pemuda, Olahraga dan Pariwisata Kabupaten Kuningan.

c) Maps

Halaman maps menampilkan informasi peta wisata yang ada di daerah Taman Nasional Gunung Ciremai dan sekitarnya.

d) Sejarah

Halaman sejarah menampilkan informasi sejarah Kabupaten Kuningan dan Taman Nasional Gunung Ciremai.

e) Wisata

Halaman wisata menampilkan informasi wisata-wisata yang ada di daerah Taman Nasional Gunung Ciremai untuk mengenalkan kepada masyarakat umum, dan menampilkan testimoni dari member yang telah mengunjungi wisata yang ada di daerah Taman Nasional Gunung Ciremai.

f) Kontak

Halaman kontak menampilkan informasi kontak yang dapat dihubungi oleh

3) Search pengunjung ataupun member.

Bagian ini berfungsi untuk pencarian wisata.

4) Login, merupakan bagian member yang ingin masuk ke halaman member.

5) Registrasi, merupakan bagian pengunjung yang ingin mendaftar menjadi member.

6) Slide

Bagian ini berfungsi menampilkan informasi wisata dan tambahan seperti makanan khas tradisional, seni budaya, serta fasilitas umum yang ada di sekitar Pariwisata Taman Nasional Gunung Ciremai.

7) Konten

Konten terdiri dari sidebar kiri, dan isi.

(1) sidebar kiri terdiri dari:

(a) Pesan jasa tour guide

Bagian ini berisi ajakan terhadap pengujung atau member untuk melakukan pemesanan tour guide.

(b) Wisata pilihan

Bagian ini menampilkan berbagai pilihan wisata yang ada di Parwisata Taman Nasional Gunung Ciremai.

(c) Testimoni

Bagian ini menampilkan testimoni dari pengunjung dan member.

(d) Statistik Pengunjung

Bagian ini menampilkan jumlah pengunjung yang mengunjungi website.

(2) Isi

Pada bagian isi akan otomatis berubah menyesuaikan dengan menu yang di pilih

8) Footer atau di klik oleh pengunjung.

Merupakan bagian paling bawah website yang berisikan informasi mengenai hak cipta. 
b. Rancangan Antar Muka Halaman Member

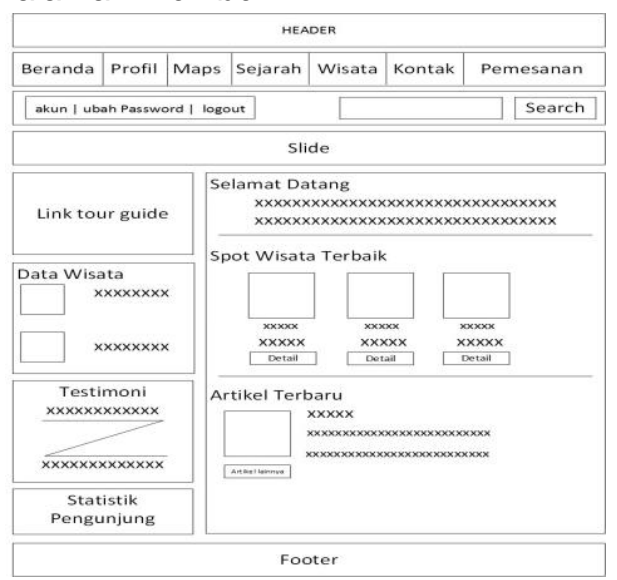

Gambar 5. Rancangan Antar Muka Halaman Member

1) Header, terdiri dari:

Header, menampilkan logo pariwisata Taman Nasional Gunung Ciremai Kuningan Jawa Barat.

2) Menu, terdiri dari:

a) Beranda

Beranda merupakan halaman awal yang dimuat saat website diakses oleh member.

b) Profil

Halaman profil menampilkan informasi tentang Dinas Pemuda, Olahraga dan Pariwisata Kabupaten Kuningan.

c) Maps

Halaman maps menampilkan informasi peta wisata yang ada di daerah Taman Nasional Gunung Ciremai dan sekitarnya.

d) Sejarah

Halaman sejarah menampilkan informasi sejarah Kabupaten Kuningan dan Taman Nasional Gunung Ciremai.

e) Wisata

Halaman wisata menampilkan informasi wisata-wisata yang ada di daerah Taman Nasional Gunung.

f) Kontak

Halaman kontak menampilkan informasi kontak yang dapat dihubungi oleh pengunjung ataupun member.

g) Pemesanan

Halaman pemesanan menampilkan data pemesanan paket wisata yang telah member pesan. Di dalam data pemesanan terdapat detail dan konfirmasi pembayaran.

(1) Detail

Pada bagian ini menampilkan detail pemesanan paket wisata yang telah member pesan.

(2) Konfirmasi pembayaran

Pada bagian ini menampilkan form konfirmasi pembayaran yang harus diisi untuk

9) Search member.

Bagian ini berfungsi untuk pencarian wisata.

10) Akun, merupakan akun member yang sedang login.

11) Ubah password, merupakan bagian member untuk mengubah password member.

12) Logout, merupakan bagian untuk keluar dari halaman member.

13) Slide

Bagian ini berfungsi menampilkan informasi wisata dan tambahan seperti makanan khas tradisional, seni budaya, serta fasilitas umum yang ada di sekitar Pariwisata Taman Nasional Gunung Ciremai. 
14) Konten

Konten terdiri dari sidebar kiri, dan isi.

a) sidebar kiri terdiri dari:

(a) Pesan jasa tour guide

Bagian ini berisi ajakan terhadap pengujung atau member untuk melakukan pemesanan tour guide.

(b) Wisata pilihan

Bagian ini menampilkan berbagai pilihan wisata yang ada di Parwisata Taman Nasional Gunung Ciremai.

(c) Testimoni

Bagian ini untuk menampilkan testimoni dari pengunjung dan member.

(d) Statistik Pengunjung

b) Isi

Bagian ini menampilkan jumlah pengunjung yang mengunjungi website.

15) Footer

Pada bagian isi akan otomatis berubah menyesuaikan dengan menu yang di pilih atau di klik oleh pengunjung.

Merupakan bagian paling bawah website yang berisikan informasi mengenai hak cipta.

c. Rancangan Antar Muka Halaman Admin

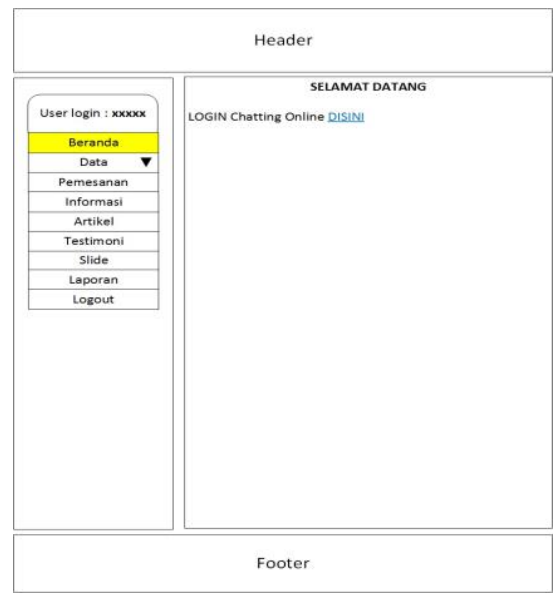

Gambar 6. Rancangan Antar Muka Halaman Admin

1) Header

Berisi judul halaman utama admin.

2) Menu, terdiri dari:

a) Beranda

Pada menu beranda berisi ucapan selamat datang dan login chatting online disini.

b) Data

(1) Admin

Pada menu data admin berisi daftar data admin yang dapat mengakses dan masuk ke halaman admin.

(2) Member

Pada menu data member berisi daftar data member yang dapat melakukan pemesanan paket wisata pada website.

(3) Pariwisata

Pada menu data pariwisata berisi daftar paket wisata yang ada di Taman Nasional Gunung Ciremai.

(4) Fasilitas

Pada menu data fasilitas berisi fasilitas-fasilitas yang terdapat di tempat wisata.

(5) Paket

Pada menu data paket berisi daftar dan harga paket wisata yang tersedia

(6) Pemandu

Pada menu data pemandu berisi daftar identitas pemandu.

(7) Ganti Password 
Pada menu data ganti password berisi form masukan untuk mengubah password admin.

c) Pemesanan

Pada menu pemesanan berisi data pemesanan paket wisata yang dilakukan oleh member.

d) Informasi

Pada menu informasi berisi pengelolaan menu informasi yang akan ditampilkan di halaman pengunjung dan member.

e) Artikel

Pada menu artikel berisi form masukan dan data artikel yang akan ditampilkan pada website.

f) Testimoni

Pada menu ini akan muncul testimoni yang telah dikirim oleh member.

g) Slide

Pada menu slide berisi informasi wisata dan tambahan seperti makanan khas tradisional, seni budaya, serta fasilitas umum.

h) Laporan

Pada menu ini berisi laporan pemesanan paket wisata dalam periode tertentu.

i) Logout

Pada menu logout merupakan bagian untuk keluar dari halaman admin.

\section{Implementasi dan Pengujian Unit}

a. Implementasi Antarmuka

1) Admin

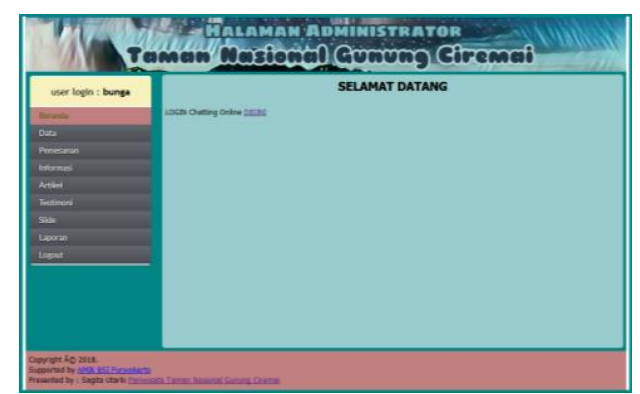

Gambar 7. Implementasi Halaman Admin

2) Pengunjung

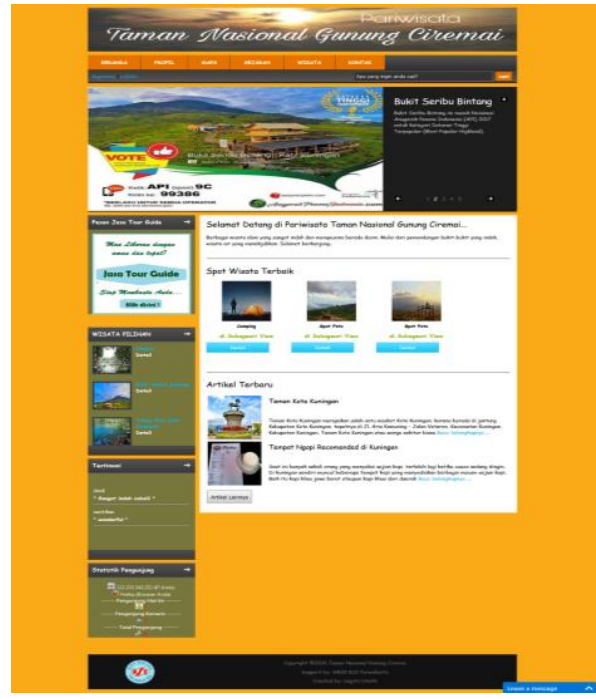

Gambar 8. Implementasi Halaman Utama Website 
3) Halaman Pemesanan Tiket

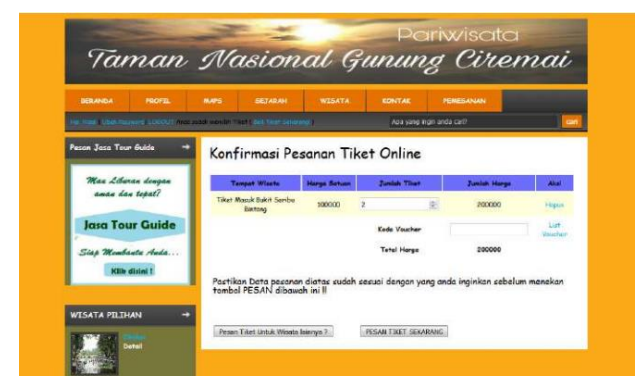

Gambar 9. Implementasi Halaman Pemesanan Tiket

4) Halaman Detail Pemesanan

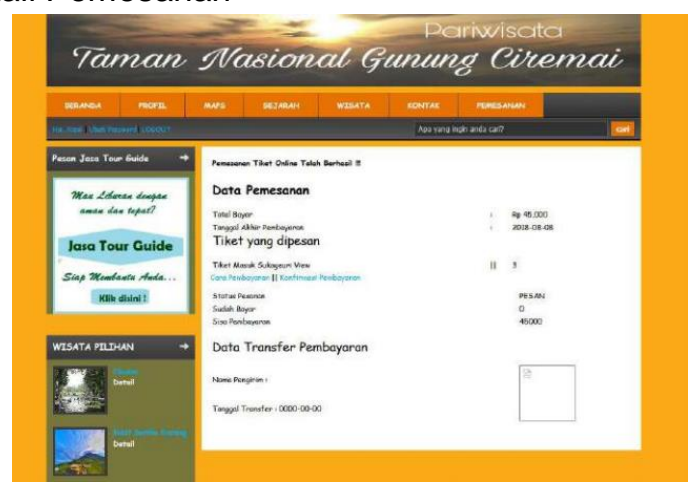

Gambar 10. Implementasi Halaman Detail Pemesanan

b. Spesifikasi Sistem Komputer

Berikut ini adalah spesifikasi perangkat keras dan perangkat lunak minimum yang dibutuhkan untuk mengimplementasikan aplikasi sistem informasi pariwisata. Spesifikasi sarana-sarana yang mendukung dalam perancangan website ini sebagai berikut:

1) Spesifikasi Perangkat Keras (Hardware)
a) Server
(1) Inte/(R) Celeron (R) CPU 1007U @1.50Ghz 1.50Ghz
(2) RAM 2GB
(3) Monitor dengan resolusi layar minimum $1024 x 768$

b) Client
(1) Inte/(R) Celeron (R) CPU 1007U @1.50Ghz 1.50Ghz
(2) RAM 2GB
(3) Monitor dengan resolusi layar minimum $1024 x 768$

2) Spesifikasi Perangkat Lunak (Software)
a) Server
(1) Sistem operasi: Windows 7
(2) Aplikasi web server yang digunakan yaitu: XAMPP yang terdiri dari beberapa komponen, diantaranya: apache, phpMyAdmin dan MySQL.
(3) Aplikasi web browser yang digunakan seperti Mozilla Firefox, Google Chome. b) Client
(1) Sistem operasi yang digunakan yaitu, Microsoft windows
(2) Aplikasi web browser yang digunakan seperti, Mozila Firefox, Google Chrome, Internet Explorer.

4. Pengujian terhadap program yang dibuat menggunakan metode black box testing agar fokus terhadap masukan dan keluaran program. 
Tabel 1. Contoh Hasil Pengujian Black Box Testing Form Pemesanan Paket Tour Guide

\begin{tabular}{|c|c|c|c|c|c|}
\hline No. & Sekenario pengujian & Test case & Hasil yang diharapkan & $\begin{array}{c}\text { Hasil } \\
\text { Pengujian }\end{array}$ & Kesimpulan \\
\hline 1. & $\begin{array}{l}\text { Kode voucher, bahasa } \\
\text { yang digunakan, } \\
\text { tanggal penjemputan, } \\
\text { lokasi penjemputan, } \\
\text { jumlah orang, tempat } \\
\text { wisata, dan keterangan } \\
\text { tambahan tidak diisi, } \\
\text { kemudian klik pesan } \\
\text { tour guide }\end{array}$ & $\begin{array}{l}\text { Kode voucher: } \\
\text { (kosong) } \\
\text { Bahasa yang } \\
\text { digunakan: } \\
\text { (kosong) } \\
\text { Tanggal } \\
\text { penjemputan: } \\
\text { (kosong) } \\
\text { Lokasi } \\
\text { penjemputan: } \\
\text { (kosong) } \\
\text { Jumlah orang: } \\
\text { (kosong) } \\
\text { Tempat wisata: } \\
\text { (kosong) } \\
\text { Keterangan } \\
\text { tambahan: } \\
\text { (kosong) }\end{array}$ & $\begin{array}{l}\text { Sistem akan menolak } \\
\text { dan akan muncul } \\
\text { pesan "Silahkan diisi" } \\
\text { pada kolom lokasi } \\
\text { penjemputan dan } \\
\text { keterangan tambahan, } \\
\text { "Silahkan dipilih" } \\
\text { pada kolom bahasa } \\
\text { yang digunakan, lalu } \\
\text { pada kolom tanggal } \\
\text { penjemputan dan } \\
\text { jumlah orang harus diisi }\end{array}$ & $\begin{array}{l}\text { Sesuai } \\
\text { harapan }\end{array}$ & Valid \\
\hline 2. & $\begin{array}{l}\text { Kode voucher dan } \\
\text { bahasa yang } \\
\text { digunakan tidak diisi, } \\
\text { tanggal penjemputan } \\
\text { diisi, lokasi } \\
\text { penjemputan tidak diisi, } \\
\text { jumlah orang diisi, } \\
\text { tempat wisata diisi, dan } \\
\text { keterangan tambahan } \\
\text { tidak diisi, kemudian } \\
\text { klik pesan tour guide }\end{array}$ & $\begin{array}{l}\text { Kode voucher: } \\
\text { (kosong) } \\
\text { Bahasa yang } \\
\text { digunakan: } \\
\text { (kosong) } \\
\text { Tanggal } \\
\text { penjemputan: } \\
\text { (isi) Lokasi } \\
\text { penjemputan: } \\
\text { (kosong) Jumlah } \\
\text { orang: (isi) } \\
\text { Tempat wisata: } \\
\text { (isi) Keterangan } \\
\text { tambahan: } \\
\text { (kosong) }\end{array}$ & $\begin{array}{l}\text { Sistem akan menolak } \\
\text { dan akan muncul pesan } \\
\text { "Silahkan diisi" pada } \\
\text { kolom lokasi } \\
\text { penjemputan dan } \\
\text { keterangan tambahan, } \\
\text { kemudian muncul pesan } \\
\text { juga "Silahkan dipilih" } \\
\text { pada kolom bahasa yang } \\
\text { digunakan }\end{array}$ & $\begin{array}{l}\text { Sesuai } \\
\text { harapan }\end{array}$ & Valid \\
\hline 3. & $\begin{array}{l}\text { Kode voucher, bahasa } \\
\text { yang digunakan, } \\
\text { tanggal penjemputan, } \\
\text { lokasi penjemputan, } \\
\text { jumlah orang, tempat } \\
\text { wisata, dan keterangan } \\
\text { tambahan diisi, } \\
\text { kemudian klik pesan } \\
\text { tour guide }\end{array}$ & $\begin{array}{l}\text { Kode voucher: } \\
\text { (isi) Bahasa } \\
\text { yang digunakan: } \\
\text { (isi) Tanggal } \\
\text { penjemputan: } \\
\text { (isi) Lokasi } \\
\text { penjemputan: } \\
\text { (isi) Jumlah } \\
\text { orang: (isi) } \\
\text { Tempat wisata: } \\
\text { (isi) Keterangan } \\
\text { tambahan: (isi) }\end{array}$ & $\begin{array}{l}\text { Sistem akan menerima } \\
\text { dan akan muncul } \\
\text { pemberitahuan } \\
\text { "Pemesanan tersimpan" }\end{array}$ & $\begin{array}{l}\text { Sesuai } \\
\text { harapan }\end{array}$ & Valid \\
\hline
\end{tabular}

\section{E. KESIMPULAN DAN SARAN}

1. Kesimpulan

Dari pembahasan diatas, dapat disimpulkan bahwa:

a) Sistem Informasi Pariwisata Berbasis Website dapat diakses kapanpun dan dimanapun oleh semua lapisan masyarakat tidak hanya masyarakat Kabupaten Kuningan saja.

b) Sistem Informasi Pariwisata Berbasis Website memudahkan masyarakat luas mengetahui informasi berbagai macam wisata menarik yang ada di Taman Nasional Gunung Ciremai Kabupaten Kuningan sehingga dapat meningkatkan jumlah kunjungan wisatawan.

c) Dengan adanya Sistem Informasi Pariwisata Berbasis Website dapat menjadikan nilai tambah untuk meningkatkan pendapatan Kabupaten Kuningan. 


\section{Saran}

Dari kesimpulan berikut adalah saran-saran yang dapat diberikan:

a) Selalu memperbaharui isi website agar pengunjung semakin tertarik dengan website Pariwisata Taman Nasional Gunung Ciremai.

b) Rutin melakukan backup data file database dan file website agar tidak hilang jika sewaktu-waktu terjadi hal yang tidak diinginkan.

c) Mengganti password admin secara berkala minimal setiap bulan untuk mencegah terhadap pencurian data.

d) Dibutuhkan sistem keamanan yang baik dikarenakan aplikasi dijalankan secara terpusat, sehingga apabila server di pusat down maka sistem aplikasi tidak bisa berjalan.

e) Diperlukan tampilan grafik kunjungan wisatawan setiap objek wisata yang ada di Taman Nasional Gunung Ciremai, supaya masyarakat luas dapat mengetahui objek wisata yang sering dikunjungi.

\section{REFERENSI}

A.S R, Shalahuddin M. 2013. Rekayasa Perangkat Lunak. Bandung: Informatika.

Handayani VR, Wijianto R, Anggoro A. 2018. Sistem Informasi Pendaftaran Seleksi Kerja Berbasis Web Pada Bkk (Bursa Kerja Khusus) Tunas Insan Karya Smk Negeri 2. J. Evolusi 6: 76-84.

Imaniawan FFD, Elsa UM. 2017. Sistem Informasi Penjualan Sepatu Berbasis Web Pada Vegas Hyper Purwokerto. 3: 82-91.

Novena KV. 2013. Pengaruh Bauran Promosi Terhadap Keputusan Kunjungan Konsumen Pariwisata. Fak. Ekon. Ka Dan Bisnis Univ. Diponegoro Semarang: 22.

Prasetyo E. 2015. Rancang Bangun Sistem Informasi. J. Inform. 1: 19-30.

Rizaniar FN, Sardiarinto. 2015. Perancangan Sistem Informasi Wisata Air di Daerah. J. Evolusi 3: $41-48$.

Saryoko A. 2017. Sistem Informasi Tiket Bioskop Pada Buaran Teater di Jakarta Timur Berbasis Web. J. Pilar Nusa Mandiri 13: 98-102.

Solichin A. 2016. Pemrograman Web dengan PHP dan MySQL. Jakarta: Universitas Budi Luhur. $122 \mathrm{p}$.

Supriyatna A. 2015. Perpustakaan Dengan Menggunakan Pieces Framwork. Pilar Nusa Mandiri XI: 43-52.

Wiguna W. 2017. Adopsi Sistem Informasi Akademik Perguruan Tinggi. J. Inform. 4: 189-197.

Zebua M. 2016. Inspirasi Pengembangan Pariwisata Daerah. Yogyakarta: Depublish. 354 p. 